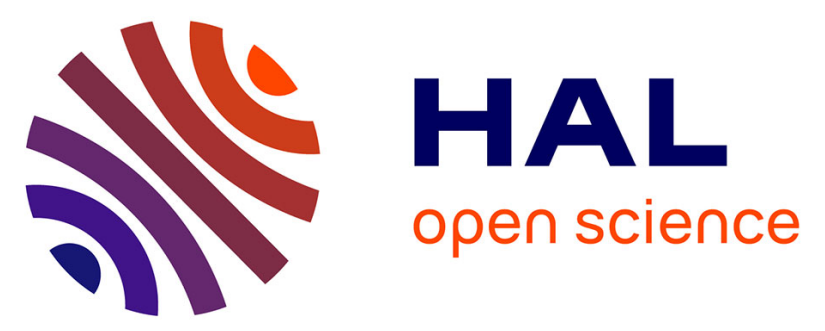

\title{
PHYLOGENY AND RESISTANCE PROFILES OF HIV-1 POL SEQUENCES FROM RECTAL BIOPSIES AND BLOOD
}

Terese Lea Katzenstein, Ann Berith Petersen, Merete Storgaard, Niels Obel, Søren Jensen Fangel, Claus Nielsen, Louise Bruun Jørgensen

\section{To cite this version:}

Terese Lea Katzenstein, Ann Berith Petersen, Merete Storgaard, Niels Obel, Søren Jensen Fangel, et al.. PHYLOGENY AND RESISTANCE PROFILES OF HIV-1 POL SEQUENCES FROM RECTAL BIOPSIES AND BLOOD. Journal of Medical Virology, 2010, 82 (7), pp.1103. 10.1002/jmv.21796 . hal-00552409

\author{
HAL Id: hal-00552409 \\ https://hal.science/hal-00552409
}

Submitted on 6 Jan 2011

HAL is a multi-disciplinary open access archive for the deposit and dissemination of scientific research documents, whether they are published or not. The documents may come from teaching and research institutions in France or abroad, or from public or private research centers.
L'archive ouverte pluridisciplinaire HAL, est destinée au dépôt et à la diffusion de documents scientifiques de niveau recherche, publiés ou non, émanant des établissements d'enseignement et de recherche français ou étrangers, des laboratoires publics ou privés. 


\section{PHYLOGENY AND RESISTANCE PROFILES OF HIV-1 POL SEQUENCES FROM RECTAL BIOPSIES AND BLOOD}

\begin{tabular}{|r|l|}
\hline Journal: & Journal of Medical Virology \\
\hline Manuscript ID: & JMV-09-1494.R2 \\
\hline Wiley - Manuscript type: & Research Article \\
\hline Date Submitted by the & 12 -Feb-2010 \\
\hline Complete List of Authors: & $\begin{array}{l}\text { Katzenstein, Terese; Rigshospitalet, Department of Infectious } \\
\text { Diseases } \\
\text { Petersen, Ann Berith; State Serum Institute, Virology } \\
\text { Storgaard, Merete; Aarhus University Hospital, Skejby, Department } \\
\text { of Infectious Diseases } \\
\text { Obel, Niels; Rigshospitalet, Department of Infectious Diseases } \\
\text { Jensen Fangel, Søren; Aarhus University Hospital, Skejby, } \\
\text { Department of Infectious Diseases } \\
\text { Nielsen, Claus; State Serum Institute, Virology } \\
\text { Jørgensen, Louise; State Serum Institute, Virology }\end{array}$ \\
\hline Keywords: & \begin{tabular}{l} 
HIV resistance, anatomical site, viral RNA, proviral DNA \\
\hline
\end{tabular} \\
\hline
\end{tabular}

\section{scholarONE" \\ Manuscript Central}


Table I. Patient characteristica.

The CD4 cell counts, viral load and treatment regimen at time of biopsy and concurrent plasma and PBMC sampling is given. Number of previous NRTI's, NNRTI's and PI's is listed.

ABC; Abacavir, AZT; Zidovudine, APV; Amprenavir, ddI; Didanosine, EFV; Efavirenz, 3TC; Lamivudine, LPV/RTV; Lopinavir/Ritonavir.

$297 \times 209 \mathrm{~mm}(300 \times 300$ DPI $)$ 
Table II. Mutations at positions conferring resistance against protease inhibitors. The samples collected at time of rectal biopsies shades light gray. Samples that could not be amplified are shades dark gray.

\section{$297 \times 209 \mathrm{~mm}(300 \times 300 \mathrm{DPI})$}


Table III. Mutations at positions conferring resistance against reverse transcriptase inhibitors. The samples collected at time of rectal biopsies shades light gray. Samples that could not be amplified are shades dark gray.

\section{$297 \times 209 \mathrm{~mm}(300 \times 300 \mathrm{DPI})$}




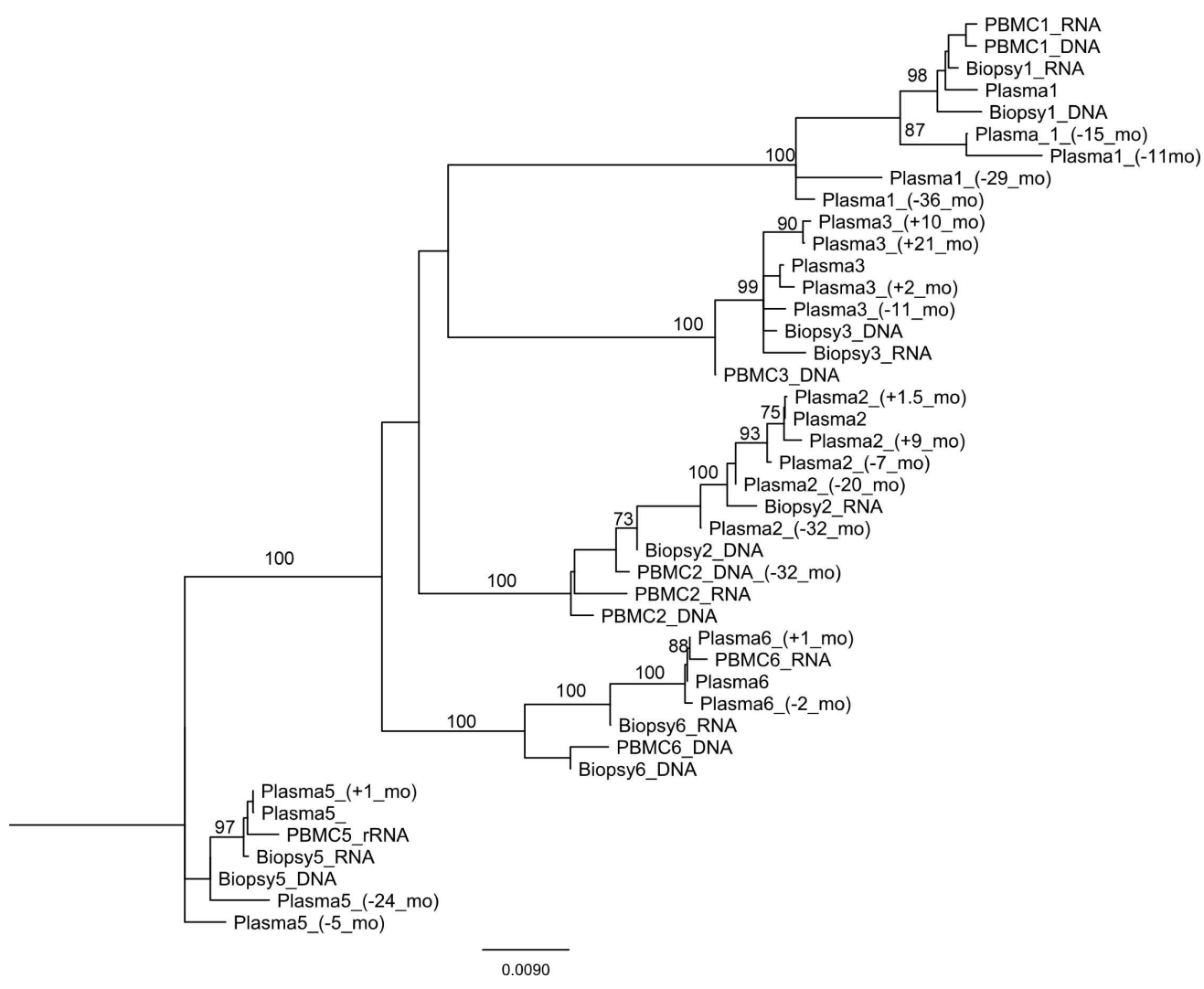

$184 \times 148 \mathrm{~mm}(309 \times 309$ DPI $)$ 
PHYLOGENY AND RESISTANCE PROFILES OF HIV-1 POL SEQUENCES FROM

RECTAL BIOPSIES AND BLOOD

3

4 TL Katzenstein $^{1}, \mathrm{AB}$ Petersen ${ }^{2}$, M Storgaard ${ }^{3}, \mathrm{~N} \mathrm{Obel}^{1}$, S Jensen-Fangel ${ }^{3}$, 5 C Nielsen $^{2}$, LB Jørgensen ${ }^{2}$.

6

$7 \quad$ 1) Department of Infectious Diseases, Rigshospitalet, Copenhagen, Denmark.

8 2) Virus BL3 Laboratory, Department of Virology, State Serum Institute,

9 Copenhagen, Denmark

10 3) Department of Infectious Diseases, Aarhus University Hospital, Skejby, Aarhus, 11 Denmark 12 13

14 E-mail: lob@ssi.dk 15

16 *Correspondence to:

17 Louise Bruun Jørgensen, Department of Virology, 18 State Serum Institute,

19 Artillerivej 5,

202300 Copenhagen S.

21 Phone: +4532683268

22 FAX: +4532683868.

23

24

25 Short title: HIV-1 sequences in rectal biopsies and blood 


\section{ABSTRACT}

The phylogeny and resistance profiles of human immunodeficiency virus type 1 (HIV1) protease $(P R)$ and reverse transcriptase $(R T)$ sequences were compared among six patients with HIV-1 who had received numerous treatments. RNA and DNA fractions were obtained from concurrent blood and rectal biopsy samples.

Phylogenetic trees and resistance profiles showed that the rectal mucosa and the peripheral blood mononuclear cells (PBMCs) harboured different HIV-1 strains. The resistance-associated mutations found in each strain corresponded to the treatment history of the patients. The resistance mutations acquired during earlier treatment regimens were detected in the sequences obtained from the rectal samples and in the PBMCs in several of the patients. Also, differences in the resistance profiles were observed between anatomical sites and between RNA and DNA fractions. Thus, a single sample probably will not be representative of the HIV-1 archived in different sites. Both the resistance profile and phylogeny of HIV-1 often differed in sequences obtained from RNA and DNA from the same site. These findings suggest that additional information regarding the antiviral resistance profile of the patient might be obtained by testing different anatomical sites.

Keywords: HIV resistance, anatomical site, proviral DNA, viral RNA 


\section{INTRODUCTION}

Human immunodeficiency virus type 1 (HIV-1) exists in chronically infected patients as a diverse population of related genetic variants. It persists as a reservoir, capable of rebounding, either in the absence of drug treatment or by evolution of resistant escape mutants. From this reservoir, integrated proviral DNA of the HIV-1 genome can add to the replicating pool of virus upon cellular activation. Several anatomical sites are potential reservoirs for HIV-1, and several studies have shown diverse virus evolution at the different sites (Blankson et al., 2002; Finzi et al., 1997; Kemal et al., 2003; Pantaleo et al., 1991; Tirado et al., 2004).

The intestinal mucosa contains most of the body's lymphoid tissue (Kotler, 2005); thus, it is potentially a vast site for persistent HIV-1 infection. The rectal mucosa is part of the intestinal compartment. Several studies have shown that detectable levels of proviral DNA and HIV RNA were present in rectal biopsies of HIV-1 infected patients, even when the plasma HIV-RNA levels were below the limit of detection (Anton et al., 2003; Monno et al., 2003). Therefore, rectal mucosa might serve as a reservoir of HIV-1 and harbour resistance mutations from earlier time periods. Furthermore, due to the pharmacokinetics of antiretroviral drugs suboptimal concentrations might be obtained at the rectal mucosa allowing development of resistant HIV-1 variants.

The aim of the present study was to determine whether the rectal mucosal was a reservoir that harboured variants of HIV-1 not found in the plasma. We compared the RNA and DNA resistance profiles and phylogeny of HIV-1 obtained from three different anatomical sites: rectal biopsies, peripheral blood mononuclear cells (PBMCs), and plasma from patients that underwent highly active antiretroviral treatments (HAART). 


\section{MATERIALS AND METHODS}

\section{Patients}

Intestinal tissue and blood samples were collected from six patients with HIV infections in November, 2001. All patients had received HAART for several years, and showed virological failure. The patients exhibited a substantial number of resistance mutations, based on examinations of plasma HIV RNA circulating in the blood. The patient characteristics are given in Table I. The study was approved by the Danish National Committee on Biomedical Research Ethics (no. 2001 0197). Written informed consent was obtained from all patients.

In all six patients, HIV RNA was obtained from plasma and had been tested previously for HIV-1 resistance as part of a routine follow-up analysis with the Viroseq, HIV-1 Genotyping System version 2, (Abbott diagnostics, Foster City, USA).

\section{Rectal biopsies}

Two rectal mucosa biopsies were obtained from each patient. Biopsies were kept at $-80{ }^{\circ} \mathrm{C}$ until nucleic acid extraction was performed. Concurrent with the biopsy, blood was collected in tubes containing EDTA, separated into plasma and PBMC fractions, and stored at $-80^{\circ} \mathrm{C}$.

\section{Extraction of viral DNA and RNA from rectal tissue and PBMCs}

PBMCs were isolated from $500 \mu$ l blood by centrifugation at $16,000 \times \mathrm{g}$ for $3 \mathrm{~min}$. The supernatant was then removed, and $1 \mathrm{ml}$ of PBS was added to wash the cells. The sample was vortexed briefly and cells were collected after a second 
101 centrifugation.

102

103 PBMC and rectal biopsies were homogenised in buffer with a micro-homogeniser.

104 Then, DNA and RNA were isolated with the Qiagen combined RNA/DNA kit (Qiagen,

105 Hilden, Germany), according to the manufacturer's instructions. Additional washing

106 steps were added to avoid contamination of RNA fragments with DNA.

107

108 Amplification of the pol gene

109 The protease region (PR) and part of the reverse transcriptase (RT) region (strain

HXB2, position 2136-3462) of the HIV-1 polymerase gene (pol) were separately

111 amplified from the DNA and RNA extracted from rectal biopsies and PBMCs. Nested

112 PCR procedures were performed, and positive and negative controls were included

113 in each set up. To prevent contamination between tests, RNA and DNA from

114 different fractions of the same patient were amplified on separate runs. To assess

115 whether RNA preparations were contaminated with HIV DNA, nested PCR assays

116 were performed without a previous reverse transcriptase step. Additionally,

117 phylogenetic analyses were performed to control for PCR contamination and sample 118 mix-ups between patients.

cDNA synthesis

121 cDNA was synthesised from RNA fractions with MuLV reverse transcriptase (Applied 122 Biosystems, Foster City, USA). The conditions were as follows: the mixture was

123 heated to $65{ }^{\circ} \mathrm{C}$ for 2 min and cooled to $42{ }^{\circ} \mathrm{C}$ before adding MuLV reverse

124 transcriptase; then it was incubated at $42{ }^{\circ} \mathrm{C}$ for $60 \mathrm{~min}$. 
127 The PR gene was amplified with nested PCR primers: 5'Prot1 (5' AGG CTA ATT

128 TTT TAG GAA GAT CTG GCC TTC C 3'), which corresponded to positions 20781292109 of HXB2; 5'Prot2 (5' TCA GAG CAG ACC AGA GCC AAC AGC CCC ACC AG 130 3'), which corresponded to positions 2136-2167 of HXB2; 3'Prot1 (3' GCA AAT ACT 131 GGA GTA TTG TAT GGA TTT TCA GG 3'), which corresponded to positions 27341322703 of HXB2; and 3'Prot 2 (5' ATT GCT TTT ATT TTT TCT TCT GTC AAT GGC 133 3'), which corresponded to positions 2650-2621 of HXB2. AmpliTaq DNA polymerase 134 (Applied Biosystems, Foster City, USA) was used for both PCR runs. The cycling 135 conditions for the first PCR run were as follows: 35 cycles that consisted of $30 \mathrm{~s}$ at 136 $95^{\circ} \mathrm{C}, 30 \mathrm{~s}$ at $55^{\circ} \mathrm{C}$, and $30 \mathrm{~s}$ at $72^{\circ} \mathrm{C}$. The cycling conditions for the second PCR 137 were as follows: 35 cycles that consisted of $30 \mathrm{~s}$ at $95^{\circ} \mathrm{C}, 30 \mathrm{sec}$ at $59^{\circ} \mathrm{C}$, and 1 min $13830 \mathrm{~s}$ at $72{ }^{\circ} \mathrm{C}$.

139

140 PCR amplification of the RT encoding sequences.

141 A nucleotide fragment of 1008 base pairs that corresponded to positions 2454-3462 of 142 HXB2 was amplified with a nested PCR procedure, as described by Nijhuis et al 143 (Nijhuis et al., 1995).

144

145 Population based sequencing. The primers used to sequence the PR gene were 146 5'Prot2 and Pr 2 (5' CTT TTG GGC CAT CCA TTC 3'), which corresponded to 147 positions 2610-2593 of HXB2. The primers used to sequence the RT gene were 148 RT-19; B-RT (5' GAT GGA AAG GAT CAC C 3'), which corresponded to positions 149 3004-3019 of HXB2; and K-RT (5' CAG GAT GGA GTT CAT AAC 3'), which 150 corresponded to positions 3258-3241 of HXB2. 
152 Viral RNA extraction and sequencing of the pol gene from plasma samples

153 Viral RNA was extracted from plasma and sequenced with the Viroseq, HIV-1

154 Genotyping System, version 2 (Abbott, Wiesbaden, Germany). A 1.8-kilobase (kb)

155 amplicon was generated by reverse transcription-PCR amplification and sequenced.

156 This provided sequence data for codons 1-99 of the PR gene and 1-320 of the RT

157 gene. The sequences were assembled and analysed with the HIV-1 Genotyping

158 System software version 2 (Abbott, Wiesbaden, Germany).

159

160

Sequence alignment, phylogeny, and interpretation of drug resistance

161 Mutations at resistance conferring positions in the HIV RT and PR regions were

162 scored according to the mutation list from the Stanford HIV RT and PR sequence

163 database (http://hivdb.stanford.edu/). The scores for resistance mutations in the

164 rectal RNA and DNA fractions were compared to the scores for mutations found in

165 the plasma viral RNA and PBMC RNA and DNA fractions. Comparisons were also

166 made among the available sequences from earlier and later time-points during the

167 infection of each patient. The scores for resistance mutations in all fragments and

168 time-points were compared with the treatment history of each patient.

169

170 The sequences were also compared by phylogenetic analyses. Fragments from each

171 of the PR and RT sequences were merged before the sequences were aligned. This

172 was performed with the CLUSTAL-W (Thompson et al., 1994) programme from

173 Geneious software (ver.Pro.4.75),(Biomatters, Auckland, New Zealand) with the

174 default settings. The Kimura two-parameter model (Kimura, 1980) in Geneious was

175 used to calculate the pairwise nucleotide distances. The phylogenetic trees were

176 constructed with the neighbour-joining algorithm, (Felsenstein, 1991) integrated in

177 the Geneious package. The trees were bootstrapped with 100 replications to test for 
178 the significance of the branches of the tree with Geneious Tree Builder.

179

180 The overall amino acid divergence of the subtype B pol gene was calculated using

181 the HXB2 strain (acc. nr K03455) as reference. The calculations were performed both

182 with and without drug resistance mutations. To analyse the intra-patient divergence

183 in drug resistance mutations, the amino acids at resistance-conferring codons in the

184 PR and RT genes were compared among samples from different tissues. For

185 example, plasma RNA sequences collected at the time of biopsies were compared to

186 PBMC and rectal biopsy sequences that had been collected concurrently. The

187 percentage of discordance in both genes was calculated by comparing RNA from

188 plasma with RNA and DNA from other compartments for each patient.
190

191

192 The treatment history, viral load, and CD4-positive cell counts for the patients are

193 shown in Table I. Plasma, PBMCs, and rectal biopsies were obtained from all six

194 patients. The resistance-conferring mutations for the $\mathrm{PR}$ and $\mathrm{RT}$ regions are shown

195 in Tables II and III, respectively. Furthermore, Tables II and III present a total of 20

196 pol sequences that were obtained from plasma samples collected at time points prior

197 to the biopsy date. It was not possible to amplify material from all the samples for

198 sequencing. Patient 4 was infected with subtype $C$, while all the other patients were

199 infected with subtype B HIV-1.

200

201 The resistance profiles of samples obtained concurrently from the different

202 compartments showed different levels of variation (Tables II, III). The resistance

203 profiles of all included samples for the PR gene are shown in Table II. The resistance 
204 profiles corresponded well to the treatment histories for the individual patients (Table 205 I -III). Samples from patients 1, 5, and 6 that were taken at the time of biopsy (light 206 gray shading) showed that the resistance profiles found in the plasma were not very 207 different from those found in PBMC and biopsy samples 208 The resistance profiles from the various compartments also showed a high degree of 209 concordance in the RT region. However, some variations between compartments 210 were noted in the RT gene (Table III). 211

212 The RNA fractions of HIV sequences collected concurrently from each patient 213 showed variable levels of variation; for example, the samples from patient 2 showed 214 moderate divergence and the samples from patient 5 showed full concordance 215 (Table II, III). A similar level of variation was observed in the DNA fractions from 216 patients 1,3 , and 6 (Table II). The patients that harboured subtype B of HIV showed 217 an average of $6-14 \%$ overall divergence compared to HXB2 when drug resistance 218 mutations were included, and 3-9\% when drug resistance mutations were excluded. 219 At the resistance conferring positions, the level of discordance for each patient was 220 calculated between the profiles in plasma RNA and the other samples. This 221 discordance ranged from 0 to $51 \%$ in the PR region and 3 to $37 \%$ for the RT region. 222

223 A phylogenetic tree was constructed that included the pol sequences from all 224 available samples collected from the five patients that were infected with subtype B 225 of HIV (Fig. 1). The samples from each patient formed a monophylogenetic cluster 226 with $100 \%$ bootstrap support; this indicated that contamination among patients was 227 successfully avoided in the PCR amplifications. 
230 biopsy. The samples from the time of biopsy were scattered throughout the 231 phylogenetic tree. The sequences did not show any particular placement in the 232 phylogenetic tree; however, the plasma sample obtained at the same time as the 233 biopsy tended to group with samples taken a few months before and after the date of 234 sampling. This was especially true for patients 1 and 6 . Three PBMC RNA samples 235 were located at the tips of the clusters for patients 1, 5, and 6; but, the PBMC RNA 236 from patient 2 was placed closer to the root of the tree. For PBMC DNA, the samples 237 from three patients (2, 3, and 6) represented phylogenetically older isolates; but this 238 was not the case for patient 1 , and no samples were available for patient 5. Likewise, 239 there was no clear pattern with regard to the phylogenetic position of the rectal 240 biopsy samples (DNA and RNA; Figure 1).

\section{DISCUSSION}

244 In this study, the PR and RT sequences of HIV-1 RNA and DNA from blood were 245 compared to those of the rectal mucosal biopsies from six patients infected with 246 HIV-1 that underwent numerous treatments who had received numerous 247 antiretroviral regimens.

249 All of the patients had HIV-1 pol RNA and DNA sequences in the plasma, PBMC, 250 and rectal fractions, with a substantial number of mutations associated with 251 resistance to antiretroviral drugs. These mutations corresponded to the treatment 252 history of the patients. Several patients showed traces of previous antiretroviral 253 treatment regimens in the form of resistance mutations or reversions of resistance 254 mutations. This was probably due to the fact that they had experienced various failed 255 regimens during long periods of high viral load. In this type of patient, the viral 
256 population typically consists of a potentially wide range of viruses with different 257 resistance profiles. For example, patient 1 harboured a virus population in the rectal 258 biopsy DNA that had a G190A mutation in the RT gene. This mutation was 259 associated with resistance to non-nucleoside reverse transcriptase inhibitors 260 (NNRTIs; Table III), and the patient had previously received nevirapine (NVP) and 261 efavirenz (EFV) treatments, while the current antiretroviral treatment did not include a 262 NNRTI (Table I). The samples were collected some years ago, prior to the 263 introduction of second generation NNRTIs, PIs, and the new drug classes that target 264 CCR5 and the integrase. This is reflected both in the treatments given and in the 265 failure to obtain virological suppression. 266

267 In the phylogenetic tree (Figure 1), the pol sequences derived from the RNA and 268 DNA isolated from the blood and rectal biopsy of each patient were dispersed among 269 plasma HIV RNA sequences derived from different time points of the infection. This 270 suggested that the sequences either represented archived virus or the dominant 271 population of the recently infected cells.

272

273 The comparison between the rectal biopsy samples and the blood samples from the 274 six patients did not reveal a clear pattern in the distribution of mutations. The results 275 showed that a single site can harbour different HIV-1 proviral DNA copies, and the 276 one selected during PCR probably varies.

278 The RNA fractions found in the plasma, PBMCs, and biopsies represented 279 replicating viruses. In most of the patients, the RNA fractions from different sites 280 showed diverse resistance profiles (Table II, III) and were often separated in the 281 phylogenetic tree (Fig 1). This suggested that there was continuous replication of 
282 viruses that had been archived at different time points. This result was in line with the 283 finding that hidden resistant viruses can be rapidly recruited when a patient is 284 reverted to a previous drug regimen (Deeks et al., 2001).

285

286 Earlier studies have analysed the genotypes and resistance profiles of HIV-1 in blood 287 compared to a different anatomical site, like the rectal mucosa. For example, Di 288 Stefano et al.(Di Stefano et al., 2001) studied rectal mucosa samples from 14 HIV-1 289 positive patients and found a high level of discordance compared to blood samples 290 in the resistance positions of the RT (74.6\%) and PR (88.8\%) genes. The median 291 percentage discordance at the amino acid level was $8 \%$ in the RT and $5 \%$ in the PR. 292 In contrast, Poles et al.(Poles et al., 2001) compared HIV-1 RNAs isolated from the 293 rectal mucosa, PBMCs, and plasma from 7 HIV-1 positive patients. They found a 294 high level of concordance among the RT and PR resistance positions. In this study, 295 the median percentage discordance was $11.2 \%$ in the PR gene and $11.7 \%$ in the RT 296 gene at resistance positions in samples from different sites and time points. At the 297 amino acid level, the percent discordances were $4.8 \%$ and $2.6 \%$ for the PR and RT 298 proteins, respectively (Poles et al.,2001). Those results were similar to the results 299 found in the current study. The level of discordance at resistance positions in the PR 300 and RT genes between anatomical sites is probably due to the duration of infection, 301 the number of changes in the treatment regimen, and the level of viral load during 302 phases of failing antiretroviral treatment.

303

304 For patients with an undetectable viral load, the genotyping of proviral DNA, either 305 from PBMCs or from lymphoid tissue, might be informative. In the current study, 306 resistance mutations acquired during earlier treatment regimens were detected in 307 samples from rectal site and the PBMCs in several of the patients. This suggested 
308 that archived viruses were present in both compartments. Also, differences in the 309 resistance profiles were observed between anatomical sites and between RNA and 310 DNA fractions from the same site. Thus, a single sample probably will not be 311 representative of the HIV-1 archived in different anatomical sites. Moreover, both the 312 resistance profile and phylogeny of HIV-1 often differed in sequences obtained from 313 RNA and DNA from the same site. This suggested that HIV-1 from different time314 points of the infection were present in the same compartment.

319 ACKNOWLEDGEMENTS

320 The authors would like to thank the Jens P Nielsens Grant for supporting this study. 321 Special thanks are extended to the lab technician Lone S Hindbæk for excellent 322 technical help. 


\section{REFERENCES}

324

325 Anton PA, Mitsuyasu RT, Deeks SG, Scadden DT, Wagner B, Huang C, Macken C,

326 Richman DD, Christopherson C, Borellini F, Lazar R, Hege KM. 2003. Multiple measures

327 of HIV burden in blood and tissue are correlated with each other but not with clinical

328 parameters in aviremic subjects. AIDS 17: 53-63.

329 Blankson JN, Persaud D, Siliciano RF. 2002. The challenge of viral reservoirs in HIV-1

330 infection. Annu Rev Med,53: 557-93.

331 Deeks SG, Wrin T, Liegler T, Hoh R, Hayden M, Barbour JD, Hellmann NS, Petropoulos CJ, 332 McCune JM, Hellerstein MK, Grant RM. 2001. Virologic and immunologic consequences of 333 discontinuing combination antiretroviral-drug therapy in HIV-infected patients with 334 detectable viremia. N. Engl. J. Med. 344: 472-80.

335 Di Stefano M, Favia A, Monno L, Lopalco P, Caputi O, Scardigno AC, Pastore G, Fiore JR, 336 Angarano G. 2001. Intracellular and cell-free (infectious) HIV-1 in rectal mucosa. J. Med. 337 Virol.,65: 637-43.

338 Felsenstein J. Counting phylogenetic invariants in some simple cases. 1991. J. Theor. Biol. $339 \quad 152: 357-76$.

340 Finzi D, Hermankova M, Pierson T, Carruth LM, Buck C, Chaisson RE, Quinn TC, Chadwick 341 K, Margolick J, Brookmeyer R, Gallant J, Markowitz M, Ho DD, Richman DD, Siliciano RF. 342 1997. Identification of a reservoir for HIV-1 in patients on highly active antiretroviral 343 therapy. Science 278: 1295-300.

344 Kemal KS, Foley B, Burger H, Anastos K, Minkoff H, Kitchen C, Philpott SM, Gao W, 345 Robison E, Holman S, Dehner C, Beck S, Meyer WA, III, Landay A, Kovacs A, Bremer J, 346 Weiser B. 2003. HIV-1 in genital tract and plasma of women: compartmentalization of viral 347 sequences, coreceptor usage, and glycosylation. Proc. Natl. Acad. Sci. U. S. A. 100: 
349 Kimura M. 1980. A simple method for estimating evolutionary rates of base substitutions 350 through comparative studies of nucleotide sequences. J. Mol. Evol. 16: 111-20.

Kotler DP. HIV infection and the gastrointestinal tract. AIDS, 2005; 19: 107-17.

352

353

354

355

356

357

358

359

360

361

362

363

364

365

366

367

368

369

370

371

Monno L, Punzi G, Scarabaggio T, Saracino A, Brindicci G, Fiore JR, lambrenghi OC, Di SM, Pastore G, Angarano G. 2003.Mutational patterns of paired blood and rectal biopsies in HIV-infected patients on HAART. J. Med. Virol. 70: 1-9.

Nijhuis M, Boucher CA, Schipper P, Leitner T, Schuurman R, Albert J. 1998.Stochastic processes strongly influence HIV-1 evolution during suboptimal proteaseinhibitor therapy. Proc Natl Acad Sci USA 95(24): 14441-14446.

Pantaleo G, Graziosi C, Butini L, Pizzo PA, Schnittman SM, Kotler DP, Fauci AS. 1991. Lymphoid organs function as major reservoirs for human immunodeficiency virus. Proc. Natl. Acad. Sci. U. S. A, 88: 9838-42.

Poles MA, Elliott J, Vingerhoets J, Michiels L, Scholliers A, Bloor S, Larder B, Hertogs K, Anton PA. 2001. Despite high concordance, distinct mutational and phenotypic drug resistance profiles in human immunodeficiency virus type 1 RNA are observed in gastrointestinal mucosal biopsy specimens and peripheral blood mononuclear cells compared with plasma. J. Infect. Dis. 183: 143-8.

Thompson JD, Higgins DG, Gibson TJ. 1994. CLUSTAL W: improving the sensitivity of progressive multiple sequence alignment through sequence weighting, position-specific gap penalties and weight matrix choice. Nucleic Acids Res. 22: 4673-80.

Tirado G, Jove G, Kumar R, Noel RJ, Reyes E, Sepulveda G, Yamamura Y, Kumar A. 2004. Differential virus evolution in blood and genital tract of HIV-infected females: evidence for the involvement of drug and non-drug resistance-associated mutations. Virology,,324: 
$372 \quad$ 577-86.

373 